\title{
The effects of psychological skills training for a canoe athlete
}

\author{
You-jin Park \& Jin Hwang* \\ Jeonbuk National University
}

\begin{abstract}
[Purpose] The purpose of this studied to improve athletes' performance through sports psychological skills training and counseling of a male canoe player in high school. [Methods] One male high school athlete in J area was interviewed for sports psychological skills training and counseling, and interviewed athletes and coaches diagnosed the potential psychological problems of athletes. Through this process, the athlete gained the ability to control anxiety about the game and strengthened the attention-focused ability to increase his confidence and set a goal for improving concentration. For effective training, sports psychological counselors, athletes, and coaches met once a week to create a routine. and participated in direct training on a boat with the coach every week. Sports psychological skills, anxiety about competition, and self-management of athletes were measured before and after to confirm the effectiveness of training of athletes' psychological skills. [Results] As a result, athletes' psychological skills and anxiety decreased, their confidence increased, and their concentration, which was diagnosed as an urgent problem of athletes, improved. [Conclusions] psychological skills of athletes, psychological shortcomings of players were reinforced, thus enhancing the athletes' performance. This suggests the effectiveness and necessity of training in sports psychological skills. It is hoped that continued support will serve as an opportunity to diagnose potential psychological problems of student athletes and apply them to training to contribute to improving their performance.
\end{abstract}

Key words: psychological skill training, sports psychological consulting, routine, high school male canoe player, concentration

\section{서 론}

스포츠심리기술이란 시합에서 경기력을 최고로 높이 기 위해 자신의 생각과 감정을 조절하여, 최상의 수행을 발휘할 수 있게 하는 능력이다(Vealey, 1988). 심리기술 을 적절하게 유지하기 위하여 목표설정, 심상, 이완훈련, 주의 집중 및 루틴등과 같은 심리적 방법들을 훈련하여 심리기술을 향상시키는 것을 심리기술 훈련이라고 한다 (Yoo, 2016).

엘리트 선수들을 대상으로 진행된 일련의 선행연구에

논문 투고일 : 2020. 09. 04

논문 수정일 : 2020. 10. 09.

제재 확정일 : 2020. 11. 05.

* 교신저자 : 황진(jinh@jbnu.ac.kr).
의하면 선수들의 기술, 체력 및 전술-전략 수준은 큰 차이 가 없는 것으로 보고되었다(Kims et al., 2010; Lee, 2015). 이는 기술, 체력 수준이 비슷할 경우 결국 심리적 인 요인이 경기력을 결정한다는 주장으로 귀결되며 (Kim, 2019; Yun \& Kim, 2004; Chang et al., 2004; Jeong, 2005), 경기력에서 심리적인 요소들이 매우 중요 한 역할을 하고 있다는 점을 반증한다.

그동안 국내 스포츠 분야에서 다양한 종목을 대상으로 적용된 심리기술이 긍정적인 효과가 있다고 보고된 연구 들을 살펴보면 구체적으로 다음과 같이 분류할 수 있다. 첫째, 폐쇄 및 개방기술로 구분이 가능하다. 폐쇄기술 종 목인 체조(Jo, 2015; Jeong et al., 2017), 사격(Han, 2007), 피겨스케이팅(Chungs et al., 2007), 양궁 (Chung, 2012; Chu \& Son 2016; Choi \& Song, 
2017), 골프(Jeong \& Jeong , 2017; Kims et al., 2013; Kang \& Choi, 2003; Kim \& Seol, 2001) 등의 연구들이 다소 진행되었다. 반면, 개방기술로 연구 되어 진 종목들을 살펴보면 테니스(Sin \& Lee, 2009), 배드 민턴(Gu, 2004; Chung 2013) 유도(Chang, 2005), 야 구(Park et al., 2012), 태권도( Lim, 2013; Ju, 2003) 등으로 폐쇄기술 연구량에 비해 적은 편이다.

둘째, 심리기술훈련 긍정적인 효과에 관련된 연구들은 경쟁상태 불안 및 긴장감조절(Lee \& Yeo, 2016; Chung \& Lee 2013; Kim et al., 2010; Chung et al., 2007; Beom, 2004; Muangnapoe \& Morris, 2001) 운동지속 및 동기를 향상시킨(Park et al., 2003; Yoo $\&$ Huh, 2002) 긍정적 인지와 루틴 자동화(Han, 2004; Wegner, 2004; Shin \& Lee, 2009; Huh \& Park, 2010; Lee \& Huh, 2012) 불안감소와 집중력의 변화 (Kim, 2007; Kwon, 2009; Kim \& Kim, 2013; Yook, 2016) 자기관리에 대한 긍정적 변화(Kim, 2003; Park \& Jeon, 2003; Park \& Shin, 2006; Kim, 2010; Kim, $\mathrm{Ji}, 2010)$ 등이 보고되었다. 동시에 목표설정(Patrick \& Hrycaiko, 1998), 심상훈련(Chung \& Kim, 2017; Parks et al., 2015; Lees et al., 등, 2009), 마음챙김 (mindfulness) (2009: Won \& Eu, 2013; Kim \& Eu, 2014), 루틴(Yoos et al., 2011; Lee \& Kang , 2016), 혼잣말(Yun, 2007; Kim et al., 2015), 바이오피드백 (Hong, 2011; Sim, 2004), 자기관리(Huh, 2001; Kim $\& \mathrm{Kim}, 2014)$ 등의 연구에서 확인했듯이 경기력 향상에 도 크게 공헌하는 것으로 나타났으며, 일련의 연구결과들 을 종합해보면 종목에 관계없이 엘리트 선수들을 대상으 로 진행된 스포츠심리기술 훈련은 선수들의 심리적인 측 면에 긍정적인 영향을 미치는 것으로 증명되었다.

그러나 여전히 스포츠 현장에서 스포츠 심리기술 훈련 및 상담과 관련된 지속적인 연구결과에도 불구하고 몇 가 지 개선점 등이 지적되고 있다. 첫째, 심리기술 훈련의 혜 택을 규명한 다수의 선행연구들이 주로 인기종목 그리고 엘리트 선수들에게 편중되어 있다. 스포츠 현장에서 심리 기술 훈련 및 상담의 혜택을 소개하고 전파했다는 측면에 서 의미가 있지만 종목과 대상이 제한적이라는 문제점 있 다(Chung et al., 2017).

둘째, 대부분의 심리기술 훈련 수혜자들이 성인 선수
들에게 편중되어 있다. 이들은 이미 상위 수준의 수행능 력 및 기술을 보유한 선수들로 성인 스포츠에서 정점을 차지하고 있는 선수들이다. 이는 그동안 스포츠 심리기술 훈련의 혜택이 비인기종목의 유·청소년 선수들에게는 충 분히 적용되지 않았다는 것을 의미하며, 실제로 다양한 종목의 선수들을 대상으로 심리기술 훈련 및 상담을 적용 하고 그 혜택을 규명할 필요성을 제기한 연구( Kim, 2018; Park \& Chung, 2015; Lee \& Yun, 2013; Yun, 2005; Gang, 2003)에서 주장된 바 있다.

그동안 스포츠심리기술훈련의 효과를 보고한 몇몇 연 구에서 청소년기 선수들을 대상으로 혜택을 규명한 연구 들이 제시되었지만(Chung et al., 2017) 매우 빈약하다. 또한, 여전히 스포츠현장에서 과도한 순위경쟁 및 훈련 량, 학교생활 문제, 진로문제, 이성문제 등 엘리트스포츠 의 구조적이고 고질적인 문제점이 보고되고 있다(Kim, 2010; Han \& Kim, 2011).

카누는 아직까지 보급이 미흡하고 대중화 되지 못해 일반인들의 관심을 끌지 못하고 있는 비인기 종목 중의 하나이다. 반면, 수상에서 다양한 기술을 바탕으로 매우 높은 강도의 운동을 수행해야하기에 스포츠 심리기술이 경기력에 매우 핵심적인 역할을 하는 것으로 보고되었다 $\operatorname{Kim}(1997)$.

그동안 저항성능력, 심폐기능, 체간 등속성 등과 같이 생리적인 측면에서 몇몇 연구들이(Lee, 2018; kang, 2015; Chung, 2014; Gu et al., 2004) 보고되었다. 반 면, 청소년 카누선수들에 대한 심리적 문제점을 파악하고 이를 해결하기 위한 시도로서 심리기술훈련 혹은 상담 중 재와 같은 연구는 전무한 실정이다.

이 연구에서는 비인기 종목인 카누를 대상으로 그동안 진행되지 않았던 스포츠심리 기술훈련을 적용하고 그 혜 택을 규명하고자 하며 특히, 고등학교 카누선수를 대상으 로 진행한 연구가 전무하여 연구의 희소성과 가치가 더욱 증폭된다고 할 수 있다. 따라서 이 연구의 목적은 고교 남 자 카누선수의 스포츠 심리기술 훈련과 상담을 통해 선수 의 경기력을 향상시키기 위함이다.

\section{연구 참여자}

이 연구의 참여자는 J지역의 고등학교 3학년 카누 선 
수를 대상으로 했으며 연구 참여자는 카누 스프린트 (Canoe Sprint) 중에서 1인승 카약이 주 종목인 선수이 다. 심리기술훈련 및 상담에 대한 경험은 처음이며, 연습 할 때의 기록은 충분히 입상할 수 있는 실력을 가지고 있 었으나 시합에서는 실력을 제대로 발휘하지 못하고 마지 막 전국 대회에서 5 위권에 머물러 있다. 연구 대상자의 구체적인 특성은〈표 1)과 같다.

Table 1. Characteristics of participants

\begin{tabular}{cc}
\hline \hline Characteristics & Division \\
\hline Gender & male \\
\hline Age & 18 \\
\hline Career & 6years old \\
\hline Event & Canoe Sprint \\
\hline PST\&Counseling & NO \\
\hline Pre Competition Results & Nationals convention 5th \\
\hline \hline
\end{tabular}

\section{측정도구}

\section{1) 스포츠심리기술 검사지}

선수가 갖고 있는 스포츠 상황의 심리기술을 측정하기 위해 Yoo \& Huh(2002)이 개발한 스포츠심리기술 설문 지를 사용하였다. 이 검사지는 자신감, 목표설정, 집중 력, 팀 조화, 의지력, 심상, 불안조절 등 7 요인 총 28 개 문 항으로 구성되어 있다. 요인당 4 개의 문항이 배치되어 있 으며 문항의 평정은 6점 Likert 척도 (1점 $=$ 전혀 아니다, 6 점 $=$ 매우 그렇다)를 활용하였다.

\section{2) 스포츠 경쟁불안 검사지(CSAI-2)}

스포츠 경쟁불안은 Martens, Burton, Vealey, Bump $\&$ Smith, (1990)의 검사지를 이용하였다. 이 검사지는 국내에서 Lee(1993)의 검사지를 사용하였다. 이 검사지 는 인지적 상태불안, 신체적 상태불안, 상태 자신감 등 3 요인으로 구성되어 있다. 요인당 9 문항씩 총 27 문항이며 6점 Likert 척도 $(1$ 점 $=$ 전혀 아니다, 6점 $=$ 매우 그렇다) 를 활용하였다.

\section{3) 시합회상법 질문지}

시합회상법 질문 측정은 Orlick(1986)이 제시하여
Kim \& Chang(2004)이 사용한 검사지를 사용하였으 며, 시합회상법은 스포츠 심리 상담과 훈련과정에서 선수 의 심리문제를 진단함과 동시에 심리훈련을 설계하는데 필요한 정보를 찾아낼 수 있다(Kim \& Chang 2004).

\section{4) 자기관리}

$\operatorname{Huh}(2001)$ 이 제시한 자기관리 질문지를 이용했으며 이 척도는 9 개요인 총 40 개 문항으로 구성되어 있다. 이 척도를 바탕으로 $\operatorname{Kim}$ (2003)이 제시한 방법에 의거하여 각각의 문항에 대해 잘한다, 괜찮다, 잘 못한다(잘 했으 면 좋겠다)로 표기하여 자기관리를 평정하였다. 구체적 으로, '잘한다(0)'가 되어야 할 것을 찾아 표시하고 14 개 이하, 15-25개, 26-30개, 31 개 이상 등 4단계의 관리범 위를 정한 후 31 개 이상의 수준으로 향상시킬 수 있도록 1 달에 한번 씩 확인했다.

이상의 질문지를 바탕으로 연구자와 연구대상자간 반 구조화 심층면담을 실시하였다,

\section{심층면담}

면담은 선수의 심리적 특성을 파악하고 PST 정보 수 집을 위해 사용되었다. 또한 상담을 종료한 후 PST의 효 과에 대한 정보를 수집하기 위해 활용하였다. 선수의 숙 소 및 훈련장에 연구자가 직접 방문하여 선수의 훈련을 관찰하였고 효과적인 심리훈련과 선수에 대한 정보수집 그리고 선수와의 라포 형성을 위해 전문지도자와 같이 주 1 회 상담을 진행하였다.

심리기술훈련 전·후 회기마다 심층면담을 실시하였으 며 연습상황을 포함하여 시합 전·후에도 반구조화 면담 및 비구조화 면담까지 진행하였다.

\section{연구절차}

이 연구는 2019년도 4월말에 열리는 전국대회를 대비 하여 2월 초부터 5월까지 약 3개월에 걸쳐 심리기술 훈련 이 진행된 단일 피험자 설계 연구이다. 양적연구결과 도 출을 위해 스포츠심리기술 검사를 사전, 사후 측정하여 평균점수를 산출하였다. 사전 검사는 오리엔테이션이 이 루어지는 과정에서 실시하였고, 사후검사는 시합이 종료 된 10회기 프로그램에서 실시하였다. 
구체적인 내용은 〈표 2 〉와 같다.

Table 2. PST Session

\begin{tabular}{|c|c|c|}
\hline PST & Contents & Reference \\
\hline 1 & $\begin{array}{c}\text { Orientation } \\
\text { Psychological characteristics \& } \\
\text { information collection } \\
\text { Leader Counseling }\end{array}$ & $\begin{array}{c}\text { Hur (2001) } \\
\text { Eu\& Hur (2002) } \\
\text { Kim \& Jang (2004) } \\
\text { Vealy (1990) }\end{array}$ \\
\hline 2 & $\begin{array}{l}\text { By problem diagnosis } \\
\text { Goal setting }\end{array}$ & $\begin{array}{l}\operatorname{Kim}(2003) \\
\cdot \operatorname{Orlick}(1986)\end{array}$ \\
\hline 3 & $\begin{array}{c}\text { Sports psychology training } \\
\text { Routine setting for concentration } \\
\text { of race }\end{array}$ & ·Kim (2001) \\
\hline 4 & $\begin{array}{l}\text { Attention, refocus soliloquy } \\
\text { Cognitive Restructuring }\end{array}$ & $\begin{array}{l}\cdot \text { Hardy et al.(2001) } \\
\cdot \text { Hatzigeorgiadis et } \\
\text { al.(2004) }\end{array}$ \\
\hline 5 & $\begin{array}{l}\text { Mental rehearsal and } \\
\text { momentum management }\end{array}$ & $\begin{array}{l}\text { · Calmels et al.(2001) } \\
\text { ·Moritz et al.(1996) }\end{array}$ \\
\hline 6 & $\begin{array}{c}\text { Routine inspection and training } \\
\text { application confirmation } \\
\text { Race routine security and } \\
\text { plan construction }\end{array}$ & $\begin{array}{c}\cdot \text { Cohn(1990) } \\
\cdot \text { Foster et al.(2006) }\end{array}$ \\
\hline 7 & $\begin{array}{l}\text { Using my psychological skills } \\
\text { Performing a race routine }\end{array}$ & · Mesagno et al.(2008) \\
\hline 8 & $\begin{array}{l}\text { Psychological for the match } \\
\text { Check condition } \\
\text { Psychological energy level }\end{array}$ & \\
\hline 9 & $\begin{array}{l}\text { Focus on race routine } \\
\text { Using psychological skills } \\
\text { in competitions Verifying } \\
\text { and evaluating the use of } \\
\text { psychological skills after a match }\end{array}$ & ·schmidt(1975) \\
\hline 10 & $\begin{array}{l}\text { Positive attribution after a match } \\
\text { Develop a psychological training } \\
\text { plan for your next match. } \\
\text { Leader counseling }\end{array}$ & $\begin{array}{l}\text { Paquette \& Sullivan } \\
\text { (2012) }\end{array}$ \\
\hline E & Inseling: Quantitative research pos & xamination and interview \\
\hline
\end{tabular}

\section{자료 분석}

이 연구의 심리검사는 심리기술 훈련 전과 심리기술훈 련 후로 분석하였으며, 각 심리 검사요인은 SPSS 25 를 이용하여 평균 $(\mathrm{M})$ 을 사전·사후로 분석하였다.

\section{결과}

\section{PST절차별 수행내용 결과}

1) 심리기술 훈련 전 레포 형성 및 사전 측정

심리기술 훈련을 실시하기 전에 연구자는 훈련장을 수 시 방문하여 선수 및 전문지도자와의 신뢰관계(rapport) 를 구축하고자 노력하였으며, 연구대상자의 연습 및 훈련 에 참여하여 관찰하고 이에 대한 정보를 수집하였다. 이 러한 과정은 전 단계에서 지속적으로 진행되었다. 선수의 심리특성 파악을 위하여 스포츠심리기술, 경쟁상태 불 안, 자기관리, 시합회상에 대한 설문을 진행하였으며 선 수가 문제점으로 토로한 집중력과 진로에 대한 심층면담 을 실시하였다.

\section{사전상담 인터뷰내용}

상담자: 선수의 경기력을 위해 가장 필요하다고 생각하시는 것이 무엇입니까?

지도자: 선수가 신체적인 부분이나 기량적인 부분에는 우수 합니다. 그런데 선수가 집중력이 부족한 것 같습니 다. 유리멘탈 입니다. 저만 생각한 것이 아니라 상 비군을 다녀왔는데 상비군 지도자들도 똑같이 말 하구요! 고3인데 불안합니다.

선 수: 고3인데 원하는 대학에 가고 싶습니다. 될 것 같은 데 자꾸 안 되니까 짜증나고 하기 싫고...

\section{2) 심리기술훈련 진행}

\section{(1) 1 차: 오리엔테이션}

오리엔테이션은 PST에 대한 전반적인 이해와 선수의 전반적인 심리특성을 파악하는데 목적이 있다. 심리훈련 을 시작하기 전에 전문지도자와 선수를 대상으로 각각 60 분씩 면담을 실시했으며 PST에 대한 일반적 정보 및 루틴, 혼잣말, 심상훈련 등을 소개했다.

(2) 2 차: 문제 진단에 따른 목표설정

2차 상담은 선수의 전반적인 심리적 특성을 바탕으로 문제를 진단하고 이를 극복하기 위하여 목표를 설정하는 단계이다. 상담을 통해서 선수가 수행에 집중하지 못하고 주의 집중력이 가장 큰 문제점으로 부각되었으며 이는 전 문지도자 면담 및 설문과 함께 훈련관찰을 통해 확인되었 다. 선수는 훈련을 진행하는 동안 주변에 다른 팀 선수나 
조정등 다른 종목에 관심을 기울이며 자신의 훈련에 집중 하지 못하고 있었다. 구체적으로 $2000 \mathrm{~m}$ 의 장거리를 타 는 동안 자신의 훈련수행과 관련 없는 다른 종목의 선수 가 물을 마시고 있는 행동에 대한 지적, 낚시꾼들 그리고 목적지가 아닌 곳으로 시선을 돌리는 행동을 지속적으로 보이고 있었다.

이밖에 불안조절 및 선수의 자기관리가 문제점으로 제 기 되었고 이를 해결하기 위한 1 차적 목표를 선수의 집중 력향상을 위해 (kim, 2018; Kim, 2006; Shin, 2006; Park, 2004; Kim, 2003)의 연구에서 수행과정에 집중 하도록 훈련시켜 선수의 집중력향상과 불안이 감소하고 부정적인 생각을 줄였다는 선행연구에 따라 훈련 수행에 루틴을 적용하기로 했다. 이는 지도자, 선수의 협의를 거 쳐 진행하기로 했다.

(3) 3차: 스포츠심리기술교육 및 레이스 루틴

3 차 상담은 레이스 중에 요구되는 집중력에 초점을 맞 추어 적용되었으며 이를 위해 전문지도자와 60 분의 상담 을 진행하여 레이스 루틴을 만들었다. Yun(2004),의 연 구에서 루틴훈련은 선수의 주의집중의 향상과 부정적 사 고가 다소 제거되어 심리기술이 전반적으로 향상되었다 는 연구에 따라 선수의 취약점인 주의 집중의 향상을 위 해 레이스 루틴을 적용하기로 했다. 구체적으로, 선수가 레이스 중에 집중할 수 있도록 start, middle, last의 구 간을 나누어 숫자를 셀 수 있도록 하였다. 이밖에 레이스 루틴을 촉진하기 위하여 레이스 이외 전반적인 매크로 루 틴 및 시합 및 기록측정 전 미니루틴을 만들었다.

(4) 4차: 긍정적인 인지재구성

4차 상담의 목표는 긍정적인 인지재구성을 통해 레이 스루틴 실행의 자동화를 꾀하는 것이다. 초기 연습 시에 는 전문지도자의 주문대로 start, middle, last의 구간에 걸쳐 레이스 루틴이 바람직하게 실행되었다.

그러나 레이스의 횟수가 5 회 이상 진행되면서 선수의 루틴이 흐트러지고 집중력이 낮아지는 문제점이 발생했 으며, 이로 인해 선수의 부정적인 혼잣말과 짜증스러운 행 동이 나타나기 시작했다. 레이스 루틴을 다시 점검하기 위해 10 분의 휴식 시간을 가졌으며, 이후 $200 \mathrm{M}$ 레이스 가 끝날 때 마다 잘된 부분에 대해 전문지도자가 긍정적
인 강화피드백을 제공하도록 요구하였다.

또한 선수가 “또 안 돼”라는 부정적인 혼잣말을 할 경우 “이번 레이스 엔 라스트에 15 개를 꼭 세어보자!"라는 것 처럼 레이스 루틴 실행 자체에 집중하도록 유도했다. 이 러한 훈련을 레이스 전반에 걸쳐서 제공하고 선수와 전문 지도자가 만족하는 수준의 레이스 운영이 나오면 긍정적 인 결과를 획득한 것으로 간주하고 남은 훈련을 빼고 마 무리했다.

(5) 5 차: 멘탈 리허셜 및 운동량 관리

5 차 상담의 목적은 레이스 루틴의 자동화를 위해 멘탈 리허설과 에너지를 적정하게 조절하는데 있다. 레이스 루 틴을 반복적으로 적용하여 기록적인 부분에서 긍정적인 발 전이 나타났으나 루틴실행의 자동화가 여전히 미약했다.

이를 개선하기 위하여 매 레이스 전에 멘탈 리허설을 진행하였으며 구체적으로, 보트를 start라인에 세우는 것부터 시작하여 last를 통과하는 데 까지 성공적인 장면 을 그리면서 실제시합과 유사한 상황을 연출하도록 했다. 또한, 레이스가 반복되면서 기록의 편차가 발생하여 온전 한 레이스 루틴을 바탕으로 한 번의 레이스에 최선을 다 하도록 요구하고 전반적으로 레이스 횟수를 최소화여 적 정 에너지 수준을 유지하도록 요구하였다.

(6) 6차: 레이스 루틴점검 및 루틴 수정

6 차 상담의 목적은 선수가 지금까지 노력해온 레이스 루틴을 전반적으로 점검하는 것이다. 그러나 6차 상담시 선수가 어깨통증을 호소하여 전문지도자와의 협의를 통 해 레이스의 횟수를 줄이고 레이스 개별 시행 시 충분한 휴식을 취할 수 있도록 하였다. 운동량을 줄이는 대신 전 문지도자가 실제 시합시 실행하는 출발신호, 피니시 신호 를 요구해서 실제 시합 분위기를 연출하고자 노력했으며, 레이스 루틴에서는 라스트 단계에서 피치 수를 줄였다.

(7) 7차 나의 심리기술(Race routine)활용하기

7 차 상담의 목적은 어깨 통증에 대한 불안을 극복하는 것이다. 시합이 다가오는데 어깨의 통증이 좀처럼 호전되 지 않아 선수가 심리적 불안감을 느끼고 있었다.

전문지도자와의 협의를 통해 선수에게 시합과 같은 3 번(예선, 준결승, 결승)의 레이스만을 연습 하도록 했으 며 레이스 루틴에 집중하도록 요구했다. 약속한데로 3 번 
의 레이스를 마친 후 충분히 몸을 풀고 휴식을 취하도록 했다.

상담자: 현재 어떤 생각이 드니?

선 수: 아프니까 좀 불안합니다. 그런데.... 지금까지 참고 열심히 했으니까 ...

상담자: 그럼 네가 시합을 준비하기 위해 지금 가장 중요한 건 무엇이라고 생각되니?

선 수: 연습은 열심히 해서 솔직히 자신 있습니다. 시합 때 몸만 아프지 않으면 해볼 만 합니다. 그래서 아프지 않게 잘 관리해야 할 것 같습니다.

(8) 8차 시합을 위한 심리적 컨디셔닝 및 에너지 관리 8차 상담의 목적은 시합직전 컨디셔닝 유지 및 적정 에 너지를 관리하는 것이다. 에너지의 과다나 고갈은 불안과 실수의 함정에 빠질 수도 있어 시합을 위한 에너지 수준 을 잘 유지하기 위해 컨디션 조절의 중요성을 인지시켰 다. 이를 위해 전문지도자와의 협의 하에 훈련시간을 단 축한 반면 집중의 강도는 높이도록 요구했다. 예선과 결 선에 해당하는 2회 레이스 실행을 통해서 레이스루틴 점 검 및 시합에 대한 시뮬레이션을 실행해 보도록 하였다.

(9) 9차 시합에서 레이스 루틴 적용 및 시합 후 확인 9차 상담은 시합 당일에 진행되었으며 시합 전 미니 루 틴 실행 및 선수가 시합에서 레이스 루틴을 적용하도록 주문했다. 시합의 결과로 선수가 본인의 주 종목인 $200 \mathrm{~m}$ 경기에서 1 위를 차지했으며, 레이스를 운영하면서 루틴 을 잘 활용하여 다른 생각은 하지 않았다고 진술 하였다. 모두가 기뻐했으며 선수 또한, 그동안 부상을 안고도 열 심히 한 자신에게 주어진 보상에 기뼈했다.

$500 \mathrm{~m}$ 경기에서도 레이스 루틴 및 경기력은 바람직한 방 향으로 잘 진행되었으나, 배의 후미에 수풀이 걸리는 예상 치 못한 변수로 인해 보트에 문제가 생겨 3 위를 하였다.

(10) 10 차 시합 후 내적 귀인하기

10 차 상담의 목적은 선수가 시합 후 긍정적으로 귀인 하는 것에 있다. 선수가 경기력을 잘 발휘하여 좋은 성적 을 거두었지만, $500 \mathrm{~m}$ 게임에 대한 억울함을 호소하였다. 이에 선수에게 시합에서의 환경적인 이변은 선수가 통제 불가능한 상황임을 재 인지시키고 이러한 이변은 또 다시 일어날 수 있음을 이야기 하였다. 반면, 통제 가능하고 내
적인 노력으로 인해서 좋은 결과를 획득한 것에 대한 내 적 귀인을 상기시켜 자존감을 유지하도록 했다.

\section{2. 스포츠심리기술훈련 사전·사후 변화분석}

\section{1) 스포츠 심리기술검사의 양적변화 분석}

연구 대상자의 스포츠 심리기술검사의 양적변화 분석 결과는 〈표3〉과 같다. 구체적으로 스포츠심리기술 하위 요인 중 집중력 $R(+2.0)$, 자신감 $(+1.5)$, 심상 $(+1)$, 불 안조절 $R(+1)$, 목표설정 $(+1)$, 팀 조화 $(0)$, 심상 $(+1)$, 의지력 $(+0.5)$ 이 증가하였으며, 심리기술훈련 후 팀 조 화를 제외한 모든 요인에서 긍정적인 변화가 나타났다.

Table 3. Sports psychological skill change

\begin{tabular}{ccccc}
\hline \hline factor & $\begin{array}{c}\text { pre } \\
(\mathrm{M})\end{array}$ & $\begin{array}{c}\text { post } \\
(\mathrm{M})\end{array}$ & $\begin{array}{c}\text { Amount } \\
\text { of change }\end{array}$ \\
\hline & Confidence & 3 & 4.5 & +1.5 \\
& Concentration(R) & 2 & 4 & +2 \\
Sports & Goal setting & 3 & 4 & +1 \\
$\begin{array}{c}\text { psychology } \\
\text { skill }\end{array}$ & Team harmony & 3 & 3 & 0 \\
& Image training & 3 & 4 & +1 \\
& Willpower & 4 & 4.5 & +0.5 \\
& Anxiety Contol(R) & 3 & 4 & +1 \\
\hline \hline
\end{tabular}

\section{2) 스포츠 경쟁불안 양적변화 분석}

연구대상자의 스포츠 경쟁불안 양적변화 분석 결과는 〈표4〉.와 같다. 구체적으로 스포츠경쟁불안 하위요인 중 인지불안(-0.5), 신체불안(-1.2)요인이 감소하였으며, 상 태자신감 $(+2.2)$ 요인이 향상된 것으로 보아 심리기술훈 련 후 스포츠 경쟁불안 요인에 긍정적인 변화가 나타났다.

Table 4. Competitive State Anxiety Inventory change

\begin{tabular}{ccccc}
\hline \hline factor & $\begin{array}{c}\text { pre } \\
(\mathrm{M})\end{array}$ & $\begin{array}{c}\text { post } \\
(\mathrm{M})\end{array}$ & $\begin{array}{c}\text { Amount of } \\
\text { change }\end{array}$ \\
\hline CASI-2 & $\begin{array}{c}\text { Cognitive } \\
\text { Anxiety }\end{array}$ & 3 & 2.5 & -0.5 \\
& $\begin{array}{c}\text { Physical } \\
\text { Anxiety }\end{array}$ & 3.2 & 2 & -1.2 \\
& $\begin{array}{c}\text { State } \\
\text { Confidence }\end{array}$ & 2.3 & 4.5 & +2.2 \\
\hline \hline
\end{tabular}




\section{3) 자기관리 양적변화 분석}

연구대상자의 양적변화 분석 결과는 〈표5〉, 와 같다. 구체적으로 자기관리 요인의 40문항중 사전검사에서 12 개의 매우 낮은 수치를 나타냈으나 중간검사에서 18 개, 사후검사에서 25 개로 사전검사에 비해 지속적인 향상을 보였으며, 사후검사에는 2 배 이상 상승하여 스포츠심리 기술 훈련에 긍정적인 변화를 나타냈다.

Table 5. Self-Management Quantitative change

\begin{tabular}{cccc}
\hline \hline & 1st & 2st & 3st \\
\hline $\begin{array}{c}\text { Self- } \\
\text { Management } \\
\text { Quantitative }\end{array}$ & 12 & 18 & 25 \\
Amount of change & & & \\
\hline \hline
\end{tabular}

\section{4) 시합회상법 질문지 질적 변화 분석}

연구대상자의 시합회상법 질문지 질적 변화를 분석한 결과 〈표6〉와 같다. 구체적으로 연구대자는 사전에 부정 적인 표현이 많았고 시합에 대한 불안감으로 자신감이 낮 은 상태였다. 또한 매우 산만하여 훈련에 집중하지 못하 는 상황 이였으며 시합을 앞두고 선수는 지난번 시합처럼 연습 때의 경기력을 발휘하지 못할 것이라는 불안을 가지 고 있었다.

하지만, 심리기술 훈련 후 레이스 루틴실행의 향상에 따 른 집중력 상승으로 인해 자신감 있는 긍정적 혼잣말 등 을 훈련과 시합에 적용하여 활용한 결과 경기력 또한 높 게 나타났다. 결과적으로 선수의 자신감과 집중력이 향상 되었다.

Table 6. competitions recalls changes

\begin{tabular}{|c|c|c|}
\hline & Before & After \\
\hline $\begin{array}{l}\text { Before } \\
\text { the } \\
\text { game }\end{array}$ & $\begin{array}{l}\text { 'I practiced a lot but I don't } \\
\text { have confidence and what } \\
\text { if don't win a gold medal' } \\
\text { 'I think others see only me' }\end{array}$ & $\begin{array}{l}\text { "Yes, I'm coming. i’m } \\
\text { ready.” } \\
\text { “I wish the game stoked } \\
\text { as soon as possible.” }\end{array}$ \\
\hline $\begin{array}{l}\text { Durin } \\
\text { g a } \\
\text { game }\end{array}$ & $\begin{array}{l}\text { 'I can't concentrate and my } \\
\text { body is hardens.' } \\
\text { 'I think I'll Defeated again' }\end{array}$ & $\begin{array}{l}\text { "Let’s do what we do.” } \\
\text { "It’s a race routine." }\end{array}$ \\
\hline $\begin{array}{l}\text { psych } \\
\text { ologic } \\
\text { al state }\end{array}$ & $\begin{array}{l}\text { 'I think I lost the game in } \\
\text { my heart even before it } \\
\text { was over. }\end{array}$ & $\begin{array}{l}\text { He have confidence in } \\
\text { the competition. } \\
\text { Focus on routines and } \\
\text { apply positive self-talk }\end{array}$ \\
\hline
\end{tabular}

\section{5) 심리기술 훈련 사전·사후 경기력분석}

심리기술훈련을 실시하기 전 연구대상자는 선수가 기 지고 있는 연습시의 기량을 시합에서 제대로 발휘하지 못 하고 있었으며, 전국대회 5 위에 머물러 있었다. 심리기술 훈련 후 이루어진 경기에서 선수는 자신이 가지고 있는 기량을 발휘한 것으로 보이며, 전국 규모의 경기에서 자 신의 주 종목인 $200 \mathrm{M}$ 경기에서 1 위에 입상하였으며, $500 \mathrm{M}$ 경기에서도 3 위에 입상하였다.

\section{6) 시합 후 선수면담내용}

다음으로 선수와의 면담내용을 살펴보면

"항상 불안하지만 결과는 1 등만 하고 싶은 마음이 그동안 있 었어요. 하지만 훈련과 연습의 차이를 알고 심리기술에 대해 서도 배우면서 내가 스스로 현재 실력이 내가 바라는 결과와 너무 동떨어져 있다는 걸 알았어요,"

"그동안 기초훈련에 대해서 너무 가볍게 여긴 것이 조금 아 쉬워요! 또 선생님이 말씀 하신 데로 선수로서 자기관리가 중요하다는 것도 알겠어요."

"이제 내가 뭘 노력해야 하는 지도 조금은 알 것 같아요.", "첫 시합에서 1등을 해서 너무 좋아요! 자만하지 않고 더 열 심히 할께요!"

"선생님이 시합 들어갈 때 "시합이 아니라 레이스 루틴을 완 벽하게 하러가는 것이야"라고 하는 말이 기억에 남아요!", "감사합니다."

자신이 노력하면 된다는 자신감과 동시에 집중력의 중 요성 그리고 선수의 자기관리의 중요성에서도 긍정적으 로 인지했다.

\section{논의}

이 연구의 목적은 고교 카누선수 1 인을 대상으로 심리 기술훈련 및 상담을 실시하여 경기력에 미치는 영향을 규 명하는 것이다. 이 연구의 결과를 바탕으로 논의하면 다 음과 같다.

첫째, 심리기술훈련 및 상담이 선수의 자신감, 집중력, 목표설정, 심상, 의지력, 불안조절에 긍정적인 영향을 미 
치는 것으로 나타났다. 이러한 결과는 심리기술훈련이 경기력을 향상시킨다는 연구(Han, 2007; Lee \& Park, 2011; Chung \& Lee, 2013)를 지지하는 것이며, 체력 이나 기술처럼 심리기술도 훈련을 통해 향상될 수 있다는 주장(Vealey, 1988; Murphy \& Jowdy, 1992; Chang, 1996)을 증명한 것이다. 다만, 스포츠심리기술의 하위요 인에서 팀 조화의 경우에는 결과 값의 변화가 없었는데 이는 선수의 종목이 1 인승 카누라는 점에 기인된 것으로 보인다.

둘째, 심리기술훈련과 상담을 진행한 후 인지불안과 신체불안은 감소하고 상태자신감은 상승하였다. 특히, 인지불안보다 신체불안이 감소하였는데 기본적으로 선 수들에게 인지불안이 더 치명적이고 인지불안의 부정적 인 영향력이 크기 때문에 심리기술 훈련 및 상담을 통해 인지불안이 줄어들었을 때 신체불안은 더 크게 감소한다 는 선행연구(Chung et al., 2007; Lee\& Yeo, 2016: Lee, 2015)와 맥락이 유사하다. 또한, 신체불안 및 인지 불안의 감소가 자신감 향상으로 이어져 경기력에 긍정적 인 영향을 미쳤는데 이는 심리기술 훈련이 경쟁 상태불안 을 감소시키고 자신감을 향상시킨다고 보고한 선행연구 $\operatorname{Kim}$ (2002)의 연구결과와 일치한다. 이는 선수가 심리 기술훈련을 통해 '안될 거야'라는 부정적인 생각을 '이렇 게 해보자라는 긍정적인 인지로 바꿔 수행에 집중하여 효과적인 수행으로 나타났기 때문인 것으로 보여 진다.

셋째, 심리기술훈련과 상담을 통해서 자기관리의 중요 성이 인식되었고 이에 대한 향상을 나타냈다. 긍정적 시 합 결과를 위해서는 과정에 집중해야함을 인지했고 이를 위해 학생선수로서의 자기관리의 중요성을 긍정적으로 지각하였다. 자기관리 요인이 경기력을 향상시키고 경기 력에 중요한 요인인 스포츠 자신감을 높여준다는 주장 (kim, 2009; Lee \& Park, 2011; Go, 2014)에 비추어 보면, 심리기술 훈련 및 상담을 통해 자기관리가 바람직 하게 개선되었고 이를 통해 궁극적으로 운동수행 능력이 향상되었을 것으로 추측된다.

넷째, 심리기술훈련과 상담을 적용한 후 시합회상을 진행한 결과, 시합을 기다릴 정도로 선수의 마음가짐이 긍정적으로 변하였다. 선수 자신의 노력으로 향상된 실력 발휘를 기대하게 되었으며 특히, 레이스 루틴에 집중하여 좋은 시합 결과를 낼 수 있었다. 이러한 결과는, 루틴에
의해 형성된 집중력이 자신감으로 이어져 경기력이 향상 된 것으로 추론되며, 이는 효율적인 집중력에 의해 자신 감이 형성되고(Hardy, Jone \& Gould, 1996), 루틴 훈 련을 통해 주의집중이 향상되어 부정적 사고가 감소한다 는 Yun(2004)의 선행연구를 지지하는 결과라고 할 수 있다. 이는 선수의 주의 집중의 향상이 레이스의 성공경 험들이 쌓여 자신감으로 이어졌기 때문인 것으로 사료된 다.

종합해보면, 청소년 남자 카누선수에게 제공된 심리기 술훈련과 상담을 통해서 선수는 자기관리의 중요성을 기 본적으로 인식하게 되었고 긍정적인 태도 및 집중력 있는 루틴을 적용한 훈련에 참여하여 자신의 수행에 대한 집중 력으로 불안이 감소하고 자신감이 향상되었다. 이러한 혜 택은 선수의 경기력은 물론 사고의 긍정적인 변화 및 스 포츠 선수로서 새로운 경험을 통해서 자신을 바라볼 수 있는 계기를 마련하였다.

부가적으로 이 연구에서 주목할 만한 시도는 지도자와 스포츠심리 전문가가 서로 협력하여 선수의 집중력향상 에 필요한 루틴을 구성하고 이를 직접 훈련에 적용 및 그 결과를 확인하였다는 점이다. 그동안 사실 일선 현장에서 스포츠심리 상담사와 코치진과의 의사소통은 요원하였 고 코치의 기술 지도와 연계된 전문적인 심리기술 훈련 및 집중력 훈련을 하지 못한 아쉬움이 많았다(Changs et. al., 2004). 이 연구에서는 그러한 어려움을 극복하 고 집중력 향상을 통한 경기력 증대라는 목적을 가지고 선수, 지도자가 같이 공유하고 스포츠심리전문가가 진행 하는 심리기술 훈련을 전체 훈련의 일부로 받아들여 의미 있는 통합을 창출하였다.

무엇보다도 이 연구의 가장 큰 가치는 비인기종목인 카누종목에서 감수성이 예민한 남자 청소년 선수를 대상 으로 심리기술 및 상담의 혜택을 제공했다는 점이다. 특 수 목적적인 체육고등학교 남학생으로 재학하면서 외로 운 비인기종목의 선수생활을 한다는 점은 하나의 고립된 섬에서 이 사회의 일반적인 교육이나 정서와는 다른 별개 의 프로그램 속에서 살아가는 것과 다를 바 없다. 비인기 종목의 청소년 학생선수일수록 이 연구와 같이 스포츠 심 리기술훈련 및 상담의 혜택을 제공하여 선수의 자기관리 를 도모하고 학생선수로서 경기력향상 뿐 아니라 긍정적 인 사고방식을 형성하게 하는 것이 중요하다. 
아쉬운 점은 이러한 혜택이 1회성에 그쳤다는 점이다. 선수의 긍정적 변화와 지도자의 적극적인 협조에도 불구 하고 전국체전이후 여러 가지 제도적인 장치의 부재 및 행정의 연속성 미비로 인해서 후속적인 상담 혜택이 제한 되었으며, 이로 인해서 선수와 상담사의 보다 발전적인 밀접한 만남 및 관계형성이 진행되지 못했다. 청소년 학 생들을 위한 심리기술 훈련 및 상담의 제도화, 상담사의 일관적인 규칙적인 상담회기 보장 및 현장 접근의 수월성 그리고 지도자와의 통섭이 절실히 요구된다.

\section{결론 및 제언}

\section{결론}

이 연구의 목적은 청소년 카누선수를 대상으로 스포츠 심리상담 및 심리기술훈련이 경기력에 미치는 효과를 규 명하는 것이다. 3 개월간 10 회 심리기술 훈련과 상담을 통해 심리적인 변화와 경기력의 변화를 검증하였으며, 스 포츠심리기술검사, 스포츠 경쟁상태불안, 운동선수 자기 관리, 시합회상법등을 사전·사후로 비교분석하였다. 그 결과는 다음과 같다.

첫째, 심리기술훈련은 고교카누선수의 심리기술에 긍 정적인 영향을 미치는 것으로 나타났다. 구체적으로 팀 조화를 제외한 모든 요인이 증가하였다. 둘째, 경쟁불안 또한 인지적불안과 신체적 불안이 감소하였고 상태자신 감은 2 배 이상 상승하여 선수의 경기력에 긍정적인 영향 을 미치는 것으로 나타났다. 셋째, 심리기술훈련과 상담 을 진행하면서 선수가 자기관리의 중요성을 인지하고 12 개의 낮은 수치에서 18 개 그리고 사후검사에서는 25 개 까지 점진적인 향상을 보였다. 결론적으로 이 연구는 고 교카누선수에게 심리기술훈련 및 상담을 제공하여 선수 의 경기력에 긍정적인 효과를 기대해본다.

\section{제언}

이 연구의 진행과정에서 얻은 경험과 결과 그리고 연 구의 제한점을 종합하여 제언하면 다음과 같다. 첫째, 다
양한 종목의 학생선수들을 위한 체계적인 심리기술훈련 을 진행할 필요성이 있다. 여전히 학생선수들을 대상으로 진행된 연구들의 매우 희소하다.

둘째, 학생선수들의 심리기술훈련을 담당하는 전문 상 담자의 역할이 경기력을 증진하고자 하는 심리기술 훈련 및 상담에 그쳐서는 안 된다. 긍정적인 학교생활을 포함 해서 일상생활에서 긍정심리를 느낄 수 있도록 그 범위를 확대시켜야 한다.

셋째, 비인기 종목을 대상으로 심리기술훈련 및 상담 을 확대할 필요성이 있다. 비인기 종목은 예산이나 선수 의 구성에서 매우 불리하다. 스포츠심리 상담사 우선 배 치 및 규정 설립과 같은 제도적 장치를 통해서 지원해 줄 필요가 있다.

\section{참고문헌}

Chang, D. S., Kim, B. J. \& Gu, H. M,. Shin, D. S. (2004). The Effect of the Concentration Routine of a Single-Case Rifle Marksman. korea journal sport psychology, 15(1), 79-95.

Chang, D. S. (2005). The Effect of Sport Psychology Counseling and Psychological Skills Training of Elite Judo Athletes. korea journal sport psychology, 13(1), 83-104.

Chang, D. S. (2015). The Relations between ACT and Psychological Well-Being for Male Judo Athletes. The Korea Journal of Sport, 13(2), 7-16.

Chang, D. S. \& Won, S. H. (2008). The Exploration of Concentration Cues and Disturbing Factors of Elite Weight-Lifting Athletes. Korean Society of Sport Psychology, 19(3), 179-195

Calmels, C, Berthoumieux, C, \& D Arripe, L. F. (2004). Effects of an imagery training pro-gram on selective attention of national soft-ball players. The Sport Psychologist, 18, 272-296.

Chung, J. E., Yook, D. W. \& Kim, B. H. (2007). The Effects of Psychological Skill Training on Competitive State Anxiety, Performance of National Figure Skaters. korea journal sport psychology, 18(1), 33-55.

Foster, D., Weigand, D., \& Baines, D.(2006). The effect of removing superstitious behavior and in-troducing a 
preperformance routine on basketball free-throw performance. Journal of Applied Sport Psychology, 18, 167-171.

Gould. D., Eklund, R. C, \& Jackson, S. A. (1992). 1988 U. S. Olympic wrestling excellence: I. Mental preparation, precompetitive cognition, and affect. Sport Psychologist, 6(4), 358-382.

Han, M. W. (1988). Effects of Mental Training Program Application on Competitive Anxiety and Performance of Representative Female Archery Players. Korean Journal of Sport Science, 9(2), 44-55.

Han, M. W. (2004). The Effects of Han`s Psychological Skills Training Program(PSTP) for a College Rhythmic Calisthenics Player in a Single Subject Design. Korean Journal of Sport Science, 15(4), 99-114.

Han, M. W. (2007). Effects of PST Using MBTI on The Psychological Variables and Performance Scores of A Middle School Rifle Shooter. korea journal sport psychology, 18(4), 61-92.

Hardy, J., Gammage, K, \& Hall, C (2001). A descrip-tive study of athlete self-talk. The Sport Psychologist, 15, 306-318.

Hatzigeorgiadis, A., Theodorakis, Y., \& Zourbans, N. (2004). Self-talk in the swimming pool: The effects of self-talk on thought content and performance on water-polo tasks. Jounal of Applied Sport Psychology, 16(2), 138-150.

Huh, J. H. \& Park, Y. B. (2010). The Case Study of Sport Psychology Counseling and Supporting Junior Golfers. Jounal of coaching development 12(4), 127-138.

Jung, S. W. \& Lee, J. H. (2013). A Case Study of Psychological Training of Men's National Gymnastics Team Members for the London Olympics 2012. korea journal sport psychology, 24(3), 129-144.

Joshi, P., \& Bhardwaj, B. K. (2016). Personality Profile of Trait Consciousness of Male and Female Sports Persons. The International Journal of Indian Psychology, 3(34), 64, 108

Kim, B. J. (2003). The Effects of Psychological Skills Training on Mental Game and Golf Performance. korea journal sport psychology, 14(2), 213-233.

Kim, B. J. \& Chang, D. S. (2004). Designing Mental Skills Training for Elite Marksmen Using Competition Reflection. Korean Society of Sport Psychology, 15(2),
92-114.

kim, B. H. (2007). Sports and importance of psychological skills applied to actual field. Korean Journal of Sport Science, 100, 50-56.

Kim, C. H. (2010). A Study on Stress and Burnout in high School Volleyball Athletes. Journal of korean Sports Science, 19(2), 195-204.

kim, H. B. \& Ji, J. C. (2010). The Stressors and Coping Strategies in Baseball Pitchers. Korean Journal of Physical education, 49(5), 137-148.

Kim, Y. S. \& Kim, J. H. (2013). The Effects of Applying Psychological Skill Training on Level of Psychological Skill and Competitive State Anxiety in University Judo Athlets. Korean Journal of Sport Science, 24(2), 370-383.

Kim, C. H. (1997). A Study on the Causes of Stress and Methods of Coping in Korean Marathoners. Major in Physical Education Graduate School of Kyung-Hee University.

Kim, J. K. (2002). A study on the development of mental training program and the effectiveness for swimmer. Korean journal of physical education, 41(5), 177-188.

Kim, J. T. (2009). The Influences of Self-management on Satisfaction of Performance and Self-confidence in Combative Athletes. korea journal Martial Arts, 11(3), 305-318.

Kim, J. G, Park H. J, Jeong S. T. (2003). The case study of Rogers` client-centered counseling theory applied to young tennis athlete. Korean Journal of Sport Psychology, 14(4), 189-204.

Kim, K. H., Park, J. S \& Kim, J. Y., Jang, S. H (2010). The Development and Effect Analysis of Psychological Skill Training Program for Performance Improvement of National Judo Player. korea journal Martial Arts 12(3), 185-203.

Ko, H. S. (2014). The Effects of college athlete'Self-management to Sport Confidence and perceived performance. Major in Physical Education Graduate School of Kyung-Hee University

Kwon, S. H. (2009). The Effects of Psychological Skills Training on Golf Performance: A Case Study. Korean Journal of Sport Science, 20(1), 129-145.

Lee, M. S., Park, S. Y. (2011). The Effects of Psychological Skills Training Program for Elite Throwers. korea journal sport psychology, 22(2), 77-92. 
Lee, J. Y. \& Huh, J. H. (2012). Psychological Skills Training and Counseling Cases of Bowling Team. journal of Sport and Leisure Studies. 49, 861-873

Lim, T. H., (2013). Effect of Psychological Skills Training for Athletes of Taekwondo National Team in 2012 London Olympics. Korean Journal of Sport Science, 24(2), 384-399.

Mahoney, M. J. \& Avener, M. (1997). Psychology of the elite athlete: An exploratory study. Cognitive Therapy and Research, 1, 135-141.

Mamassis, G. \& Doganis, G. (2004). The effects of mental training program on juniors per-com-petitive anxiety, self-confidence, and tennis performance. Journal of Applied Sport Psycholory, 16, 118-137.

Orlick, T. \& Partington, J. (1988). Mental links to excellence. The Sport Psychologist, 2(2), 105-130.

Park, J. G. \& Jeon, J. H. (2003). The sources of stress and coping strategies in elite tennis players. Korean Journal of Sport Psychology, 14(4), 81-111.

Park, Y. S. \& Shin, J. T. (2006). The Development of Physical-Self Efficacy Inventory to Tavle-Tennis Player. Korea Journal of sport research, 17(5), 1009-1022.

Shin, M. J., \& Lee, Y. H. (2009). The Effects of Psychological
Skills Training for Men's High School Tennis Player. korea journal sport psychology, 20(3), 73-88.

Thelwell, R, C, Greenless, I. A., \& Weston, N. J. (2006). Using Psychological skills training to develop soccer performance. Journal of Applied Sport Psychology, 18, 254-270.

Yoo, J., \& Hur, J. H. (2002). Development and Validation of The Psychological Skill Questionnaire in Sport. Korean journal of physical education, 41(3), 41-50.

Yun, Y. k., \& Kim, W. B. (2004). Analytic Hierarngy Process to examine psychological factors influencing football performance. korea journal sport psychology, 15(2), 129-138.

Yun, D. H. (2004). The effects of psychological skills training on professional golfer's psychological skills and performance. doctor in Physical Education Graduate School of Chung-Nam University.

Yook, Y. S. (2016). The Effects of the Mindfulness-based Psychological Skills Training (MBPST) on Female Short Track Speed Skaters. Korean Journal of Physical education.

3, $157-173$ 


\title{
고교카누선수의 심리기술 훈련의 효과: 단일사례연구
}

\author{
박유진 ${ }^{1}$, 황진 ${ }^{2}$ \\ 1전북대학교 연구원 \\ 2전북대학교 교수
}

〔목적〕 이 연구의 목적은 고교 남자 카누선수의 스포츠 심리기술 훈련과 상담을 통해 선수의 경기력을 향상 시키기 위함이다. 〔방법) 스포츠 심리기술훈련과 상담에 J 지역의 남자 고등학교 선수 1 명을 대상으로 하였으 며 선수와 코치의 인터뷰를 통해 선수의 잠재적인 심리적 문제점을 진단했다. 이 과정을 통해서 선수가 시합에 대한 불안과 주위가 산만하여 집중력이 부족하다는 점을 도출하였으며 주의집중력과 자신감 향상을 위한 목표 를 세웠다. 효과적인 훈련을 위해 코치와 주 1회씩 협력하여 여러 차례 수정과 점검을 거쳐 선수에게 맞는 루틴을 만들었으며, 매 주 코치와 보트에 탑승하여 직접훈련에 참여하여 심리기술적용을 관찰 했다. 선수의 심리기술 훈련의 효과를 확인하기 위해 스포츠 심리기술, 경쟁불안, 운동선수 자기관리 등을 전후로 측정했다. 〔결론〕 그 결과 선수의 심리기술 향상과 불안이 감소하고 자신감이 향상되었으며, 선수의 시급한 문제점으로 진단되었던 집중력이 향상되었다. 〔논의〕 선수의 스포츠 심리기술훈련과 상담을 통해 선수의 심리적 단점은 보강되었으며 경기력에도 긍정적인 결과를 보였다. 이는 스포츠 심리기술 훈련의 효과와 필요성을 시사한 것 이다. 지속적인 지원을 통해 학생선수들의 잠재적인 심리적 문제를 진단하고 훈련에 적용해 경기력 향상에 기 여 하는 계기가 되는 것이다.

주요어: 스포츠심리기술, 스포츠심리상담, 집중력, 루틴, 남자고교 카누선수 